$>$ Tips om medisinsk litteratur, andre bøker, filmer og elektroniske medier som bør anmeldes, sendes tidsskriftet@legeforeningen.no

\section{«Jeg følte jeg var alene og prøvde å fortelle det til noen...»}

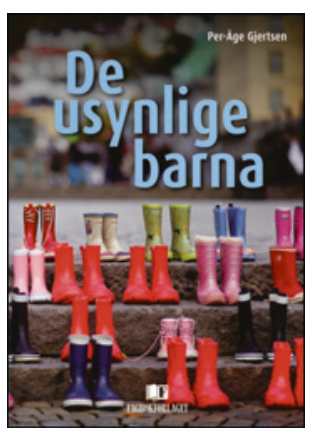

De usynlige barna

260 s, ill. Bergen: Fagbokforlaget, 2013.

Pris NOK 399

ISBN 978-82-450-1167-8
Per-Åge Gjertsen er cand.polit. og førstelektor ved Høgskolen i Sør-Trøndelag. Han har tidligere skrevet bøker om barnevern og sosialpedagogikk $(1,2)$. Hensikten med denne boken er å skape bred forståelse blant de profesjonelle i bl.a. helsetjeneste, barnevern og undervisningssektor av hvordan barn har det når de viktige voksne ikke ser at de har det vanskelig, og hvilke konsekvenser dette får. $\mathrm{Og}$, ikke minst, at det er mulig å gjøre noe for dem.

Første del er innledende teori om kunnskapsgrunnlag, -utvikling og -forståelse, så presenteres fem ulike historier om oppvekst som «usynlig barn» og til slutt kommer en refleksjonsdel. I de innledende teorikapitlene refererer forfatter relevante sosiologiske og psykologiske teorier som han så bruker til å reflektere over de fem historiene.

De fem utviklingshistoriene forteller om skole og offentlig omsorg som administrerer, men som i liten grad ser det enkelte barns særegne situasjon og behov. Hver historie er utgangspunkt for diskusjon av et tema: barn som pårørende, når barneomsorgen svikter, når skolen svikter, de ensomme og sjenerte barna og enslige, mindreårige flyktninger. Informantene har fortalt historiene til forfatteren fordi de ønsker at barn skal sikres bedre vilkår enn de har fått.

Boken dekker sentrale områder av barneomsorgen med kunnskapsgrunnlag og anvisning av hva disse barna trenger. Den er oversiktlig redigert og språket flyter lett. Referanselisten inneholder sentrale internasjonale navn og er en fyldig presentasjon av norsk forskning, evalueringsrapporter, fagbøker og populærvitenskap på feltet. Men er dette en systematisk rapport fra en intervjustudie eller en fagbok med kliniske vignetter? Oppbygningen er rapportmessig, og det kan bli noe gjentakelse mellom teoriavsnittene som gjør den tung å lese. Det er imidlertid en nyttig bok for leger som er opptatt av barn, slik som fastleger, skole- og helsestasjonsleger, pediatere og barne- og ungdomspsykiatere. Den bør ikke nødvendigvis leses fra perm til perm, men være tilgjengelig når man sitter med kliniske problemstillinger som er illustrert i historiene. Da kan man begynne der - og så gradvis lese seg videre over i teorien. På den måten kan den bli et viktig redskap for å utvide vår forståelse.

\section{Marit Hafting}

Barne- og ungdomspsykiatrisk poliklinikk Voss

Voss sjukehus

\section{Litteratur}

1. Gjertsen P-Å. Forebyggende barnevern. Samarbeid for barnets beste. Bergen: Fagbokforlaget, 2007.

2. Gjertsen P-Å. Sosialpedagogikk. Forståelse, handling og refleksjon. 2. utg Bergen: Fagbokforlaget, 2010

\section{Følelsesmessige reaksjoner på 22. juli-rettssaken}

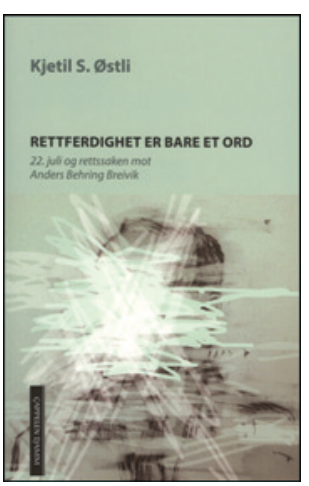

Kjetil Stensvik Østli

Rettferdighet er bare et ord

22. juli og rettssaken mot Anders Behring Breivik. 156 s. Oslo: Cappelen Damm, 2013 Pris NOK 249

ISBN 978-82-02-41126-8

Det er beklemmende å tenke på at krig, massedrap og katastrofer fort skaper arbeidsplasser gjennom produksjon av bøker, artikler, film og fjernsynsreportasjer. Bare tenk på Titanic-katastrofen i så måte. Fenomenet bekrefter det kyniske ordspråket om at den enes død er den andres brød. Så også med terroraksjonen 22. juli 2011 og den etterfølgende rettssaken. Hittil har jeg registrert fire bøker, ett teaterstykke og et ukjent antall artikler, som sikkert bare er begynnelsen.

Denne boken dekker rettssaken og er skrevet av journalist Kjetil S. Østli i Aftenposten. I de ti ukene rettssaken pågikk, trykte Aftenposten ukentlig Østlis observasjoner, tanker og følelser omkring det som skjedde i retten. Underveis fikk Østli mange positive reaksjoner fra leserne, og tanken om å samle ukerapportene til en bok kom som en naturlig følge. Spørsmålet er om det i ettertid er marked for en slik oppfrisker, særlig når mitt inntrykk er at nordmenn flest vil legge alt omkring 22. juli bak seg.

Her blir vi uke for uke delaktige i Østlis observasjoner av aktørene i rettssalen samt hans refleksjoner og følelser knyttet til dem og dramaet som foregår der. Teksten prøver å formidle stemninger og følelser fremfor å være tørre rettsreferater eller nitide analytiske granskinger.

Rettssaken ble overført på fjernsyn, men det er lite sannsynlig at NRK vil lage en redigert versjon for salg. Et slikt produkt ville dessuten neppe innholde journalistiske refleksjoner og følelser underveis. Det beste ved Østlis bok er at han på 156 små sider får formidlet såpass mye av stemningen i rettssalen, og den passer for lesere som vil gjenoppleve stemningen og bryne egne refleksjoner og følelser mot Østli sine.

Ulempen er en springende, nærmest «stream of consciousness» fremstilling som kan være vanskelig å følge uten en viss tålmodighet. Østli begrunner sitt valg av teknikk i etterordet: «Å skrive om følelser», som øker leseverdigheten. Derfor burde kanskje det kapitlet kommet først, selv om det ble skrevet sist.

Målgruppen er alle som vil ha en dypere forståelse av 22. julirettssaken, men teksten har ingen spesiell rettsmedisinsk eller rettspsykiatrisk interesse utover Østlis reaksjoner på de sakkyndige.

Pocketformatet er behagelig, layouten grei og trykkfeilene få. Når Cappelen Damm skriver på vaskeseddelen at boken er for «nå og all ettertid», er det å ta hardt $i$.

\section{Alv A. Dahl}

Oslo universitetssykehus, Radiumhospitalet 